\title{
Liquid Culture Systems Affect Morphological and Biochemical Parameters during Rosa canina Plantlets In Vitro Production
}

\author{
Małgorzata MALIK ${ }^{1 *}$, Marzena WARCHOŁ ${ }^{2}$, Bożena PAWŁOWSKA ${ }^{1}$ \\ ${ }^{1}$ University of Agriculture in Krakow, Department of Ornamental Plants, 29 Listopada 54, 31-425 Kraków, \\ Poland; romalik@cyf-kr.edu.pl(*correspondingauthor); ropawlow@cyf-kr.edu.pl \\ ${ }^{2}$ The Franciszek Górski Institute of Plant Physiology, Polish Academy of Sciences, Department of Biotechnology, Niezapominajek 21, \\ 30-239Kraków, Poland; mwarchol@ifr-pan.edu.pl
}

\begin{abstract}
Wild roses are an important group of plants used as decorative shrubs and cut flowers. They are also a row material for pharmaceutical, cosmetic and food industries. For rose in vitro propagation, solid media are commonly used. Up till now there is a few reports confirming the beneficial effect of liquid media on Rosa shoot growth and multiplication. The aim of the study was to investigate different culture systems, temporary immersion system (TIS) (immersion frequencies of 15 min every 6, 8 and $12 \mathrm{~h}$ ), rotary shaker (RS) and stationary liquid (SL) for propagation of $R$. canina and compare with solid medium culture. Shoot tips and stem explants were grown on basic Murashige and Skoog medium with $20 \mathrm{mg} \mathrm{dm}^{-3}$ FeEDDHA, $1 \mu \mathrm{M}$ BA, 1.5 $\mu \mathrm{M} \mathrm{GA}_{3}$ and 3\% sucrose for six weeks. Liquid cultures stimulated biomass growth. The highest biomass growth in RS cultures were observed however, RS reduced the shoot dry mass content. TIS cultures immersed every 6 and 8 h increased dry mass content. In TIS and on solid medium shoot multiplication was 1.5-2 times better than in other systems and stem explants were more efficient. Solid medium improved the content of chlorophyll $a, b, a+b$ and carotenoids. Higher contents of photosynthetic pigments were determined in shoot tips than stem explants. TIS-derived plantlets accumulated the largest amount of phenolic compounds. As the frequency of immersion increases the concentration of these compounds were reduced. In turn, SL cultures favored the accumulation of soluble sugars.
\end{abstract}

Keywords: axillary shoot, dog rose, photosynthetic pigments, phenolics, sucrose, temporary immersion system Abbreviations: BA - N6-benzyladenine; $\mathrm{GA}_{3}$ - gibberellic acid; FeEDDHA - ethylenediamine di-2-hydroxyphenyl acetate ferric; PPFD - photosynthetic photon flux density; S - solid medium; TIS - temporary immersion system; SL - stationary liquid; RS - rotary shaker

\section{Introduction}

The genus of Rosa consist of about 150-200 morphospecies, native to temperate regions from the northern hempishere, including Asia, Europe, North America and the Middle East (Wissemann and Ritz, 2007). In Europe, there are 47 Rosa species, belonging to 5 sections. Most of the European roses belong to the section Caninae, which is characterized by pentaploidy and unique meiosis (Popek, 2002). Rosa canina (dog rose) is the most popular species among pentaploids and in Poland most often occurs at natural sites. It is an erect shrub of up to $3.5 \mathrm{~m}$, sometimes climbing, branches often curved or arched. Petals are white to pale pink, rarely deep pink and hypanthia are orange-red. It always occurs on banks or rocky slopes, as scrubs, hedges or in forest and clearing, mainly on limestone soils
(Zieliński, 1985). These shrubs are planted for various purposes in the landscape and urban area. They are resistant to hard conditions, poor soil and water deficit, air pollution as well as tolerant to disease and pests. $R$. canina has been used as a rootstock for ornamental rose cultivars (Popek, 2002). Dog rose may become a potential source of plant material for breeding new varieties. Rosa $\times$ alba (alba rose), the oldest historical rose, discovered in the fifteen century is a hybrid of $R$. canina and $R$. gallica (Vukosavljev et al., 2013). Fruits, leaves and roots of $R$. canina are used as diuretics (Ercisli, 2005). This is a medicinal plant, with many essential natural healing properties, to which great attention is paid recently. It contains an antioxidant and antimicrobial compounds; it is rich in minerals, vitamins, sugars, phenolic compounds, carotenoids, bioflavonoid, tannins, organic acid, amino acids and volatile oils. The 
fruits are used for marmalade, jam, juices, syrups and wine (Demir and Özkan, 2001; Gunes, 2010; Cheikh-Affene et al., 2013; Stănilă et al., 2015).

Commercial propagation of $R$. canina is usually done by seeds and cuttings, but these methods are dependent on the season. Furthermore, traditional propagation is very slow and time-consuming, and the plant material is exposed to pathogens and unfavorable environmental conditions (Pawłowska, 2011; Jang et al., 2016). The alternative is in vitro techniques that offer the possibility of mass production of high quality plants in a short period of time and independently of the growing season. Solid media are commonly used for rose propagation in vitro (Pati et al., 2006; Pawłowska and Szewczyk-Taranek, 2014; Davoudi Pahnekolay et al., 2016; Kwaśniewska et al., 2017). However, culture on solid media, due to high labor and time intensity, limits the possibilities of automating the production process; it is also more expensive. Use of liquid culture systems lower the costs and increase the production scale (Berthouly and Etienne, 2005). Previous studies on the use of liquid media (static liquid, rotary shaker and temporary immersion cultures) for the production of plant tissues have shown that many species of economic interest, woody plants and ornamental plants develop better in liquid media than in agar-solidified media (Lorenzo et al., 1998; Escalona et al., 2003; Malik, 2008; Akdemir et al., 2014; Cavallaro et al., 2014; Vidal et al., 2015; Debnath, 2016; Malik et al., 2016; Ramírez-Mosqueda and IglesiasAndreu, 2016; Mosqueda Frómeta et al., 2017). In the Rosaceae, liquid systems have been applied to Malus, Prunus (Damiano et al., 2005), apple rootstock M26 (Zhu et al., 2005), Rubus (Debnath, 2014; Arencibia et al., 2013; Welander et al., 2014) and Fragaria (Debnath, 2009). A few reports confirmed the beneficial effect of liquid media on Rosa shoot growth and multiplication (Ghashghaie et al., 1991; Chu et al., 1993; Pati et al., 2005; Ginova et al., 2012; Bayanati et al., 2015; Jang et al., 2016). So far there are no studies on in vitro production of Rosa canina shoots using liquid culture systems.

The aim of the study was to investigate different liquid culture systems - temporary immersion system (TIS), rotary shaker (RS) and stationary liquid (SL) - for the $R$. canina propagation and quality improvement, and to compare them with solid medium cultures. The effect of different immersion frequencies was investigated to assess the applicability of TIS for the in vitro production of dog rose plantlets. The impact of all tested factors on biometrical traits and biochemical quality of regenerants were analyzed.

\section{Materials and Methods}

\section{Plantmaterial}

Shoot tips ( $\sim 1 \mathrm{~cm}$ long) and stem explants $(\sim 1.5 \mathrm{~cm}$ long two-node section) from in vitro plantlets of dog rose (R. canina L.), multiplicated on solid MS (Murashige and Skoog, 1962) medium with $20 \mathrm{mg} \mathrm{dm}^{-3}$ FeEDDHA, $1 \mu \mathrm{M}$ 6-benzylaminopurine (BA), $1.5 \mu \mathrm{M}$ gibberellic acid $\left(\mathrm{GA}_{3}\right)$ and $3 \%(w / v)$ sucrose and $0.5 \%$ (w/v) Lab-Agar ${ }^{\text {rx }}$ (Biocorp, Poland) and $\mathrm{pH}$ set to 5.7, were used in our experiment (Pawłowska, 2011).
A 16-hour photoperiod at PPFD $30 \mu \mathrm{mol} \mathrm{m} \mathrm{m}^{-2} \mathrm{~s}^{-1}$ (Philips TL-D 36W/54), at $23 / 25^{\circ} \mathrm{C}$ (night/day) and $70 \%$ relative humidity in a growth chamber were applied for all stages of the experiment.

\section{Culture systems for shoot development}

In the main experiment the development of shoot tips and stem explants was studied in four different culture systems: (1) medium solidified with $0.5 \%(\mathrm{w} / \mathrm{v})$ Lab-Agar $^{\mathrm{rm}}$ (Biocorp, Poland); (2) liquid medium maintained in temporary immersion system (TIS) on a RITA apparatus (CIRAD Ltd., France) with three immersion frequencies of 15 min every 6 ( 4 times per day), 8 (3 times per day) and 12 hours (2 times per day); (3) stationary liquid (SL) medium; (4) liquid medium agitated on rotary shaker (RS) at 100 rpm. Basal MS medium supplemented with $20 \mathrm{mg} \mathrm{dm}^{-3}$ FeEDDHA, $1 \mu \mathrm{M}$ BA, $1.5 \mu \mathrm{M} \mathrm{GA}_{3}, 3 \%$ (w/v) sucrose and $\mathrm{pH}$ adjusted to 5.7 were used in the experiment. Jars $(500$ $\mathrm{mL}$ capacity) filled with $50 \mathrm{~mL}$ medium were used for solid (S) cultures and Erlenmeyer flasks $(250 \mathrm{~mL}$ capacity) filled with $25 \mathrm{~mL}$ medium were used for liquid, SL and RS cultures. Five explants were placed per vessel. RITA vessels (1 L capacity) contained $200 \mathrm{~mL}$ of medium and 10 explants were placed per one vessel. After 6-week cycle of main experiment, all obtained shoots were subcultured on the MS solid medium without growth regulators for the next 6 weeks.

\section{Morphometric observations}

Biomass growth, dry mass content, multiplication rate, plant height were determined after six weeks of different culture systems. After transfer on solid media, plant height and plant height increase were measured (12th week of culture). The biomass growth was determined using the following formula: (final fresh weight (FW) - initial FW)/initial FW. The dry mass content was calculated using the formula: weight of the plant samples after drying/weight of the plant samples before drying. The samples were dried at $65^{\circ} \mathrm{C}$. Multiplication rate was calculated as the number of new shoots produced per explant.

\section{Biochemical analysis \\ Chlorophyll and carotenoid contents}

The chlorophyll $a, b$ and $a+b$, and carotenoid contents were determined spectrophotometrically using a method developed by Lichtenthaler and Wellburn (1983). Fifty mg of leaves FW were extracted in $1 \mathrm{~mL}$ of $80 \%$ ethanol and centrifuged. The extract $(200 \mathrm{~mL})$ was added to microplate wells and absorbance at 470, 648, $664 \mathrm{~nm}$ was measured spectrophotometrically with a microplate reader (Synergy II, Bio-Tek, USA). Concentrations of chlorophyll and carotenoids are expressed as pigment contents per $1 \mathrm{~g} \mathrm{FW}$ of plant tissue.

\section{The total phenolic compounds content}

To determine phenolics, $50 \mathrm{mg}$ of leaves FW for all conditions tested was homogenized in $1 \mathrm{~mL}$ of $80 \%$ (v/v) ethanol and centrifuged. The supernatant was mixed with $25 \%(w / v) \mathrm{Na}_{2} \mathrm{CO}_{3}$ and Folin-Ciocalteau reagent according to the method of Singleton and Rossi (1965). The absorbance $(\lambda=760)$ of the samples was measured 
60

spectrophotometrically with a microplate reader (Synergy II, Bio-Tek, USA).The total phenolics content was expressed as milligrams of chlorogenic acid per $1 \mathrm{~g} \mathrm{FW}$ of plant tissue.

\section{The soluble sugar content}

After homogenization of $50 \mathrm{mg}$ of leaf material, soluble sugars were extracted with $80 \%$ aqueous ethanol and centrifuged. The amount of total sugars was estimated by the phenol-sulphuric acid method (Dubois et al., 1956). The supernatant was mixed with $5 \%$ phenol and sulphuric acid. The absorbance $(\lambda=490 \mathrm{~nm})$ of the samples was measured spectrophotometrically with a microplate reader (Synergy II, Bio- Tek, USA). The content of soluble sugar was expressed as milligrams per $1 \mathrm{~g}$ FW of plant tissue.

\section{Statistical data analysis}

For each treatment, 30-60 explants were used and three replications were carried out. The average values of all data were subjected to ANOVA and assessed by Duncan's multiple range test using STATISTICA 10.0 data analysis software (StatSoft Inc., USA).

\section{Results and Discussion}

The results of our study have demonstrated the usefulness of liquid cultures systems: temporary immersion system (TIS), rotary shaker (RS), and stationary liquid (SL) for the propagation of Rosa canina with increased plant quality (Figs. 1, 2). The culture system had a significant effect on all tested traits (Tables 1,2). Liquid cultures (TIS, SL, RS) stimulated biomass growth compared to solidified medium. The highest biomass growth was observed in RS cultures, however, they reduced shoot dry mass content. TIS contributed to the increase of dry mass content in $R$. canina plantlets. This value was higher with increasing immersion frequency, and the highest values were achieved for TIS cultures immersed every 6 and $8 \mathrm{~h}$.

Thus far most of the studies have shown that plant cultures in liquid media, including roses, are characterized by high multiplication rate and, at the same time higher plant quality (Bayanati et al., 2015; Pati et al., 2005). In our study, shoot multiplication was significantly affected by the culture system and the type of explant, and the interaction between system and explant type was observed. Shoot multiplication was 1.5-2 times better in TIS than in other systems and was comparable to the value obtained on solid medium. Although SL stimulated biomass growth, it also inhibited shoot multiplication. Ghashghaie et al. (1991) reported that the elimination of the gelling agent in the medium led to a significant reduction of the multiplication rate and shoot deformation due to vitrification in Rosa bybrida 'Madame G. Delbard' cultures. There is information in the literature confirming the beneficial effect of the SL system on shoot propagation. The opposite results are due to the fact that different studies use vessels of varying volumes and shapes filled with different medium volumes. The results of Chu et al. (1993) and Pati et al. (2005) showed that the medium volume in the growing vessel influenced the growth and development of roses propagated in static cultures. More than four times higher biomass growth and more than two times higher reproduction ratio were recorded in stationary liquid cultures of Rosa chinensis 'Minima' compared to that obtained on solid media (Chu et al., 1993). An 8-fold increase in the number of shoots was observed during six weeks in SL in single-node shoot fragments of Rosa damascena and Rosa bourboniana compared with 2-fold increase obtained on solid media (Pati et al., 2005). In our experiment, more axillary shoots were formed in stem-explant-derived cultures than in case of shoot-tip-derived cultures (Table 1). Axillary shoots developed from stem explants had lower biomass and dry mass and were shorter, but they multiplicated two times better than the axillary shoots originated from shoot tips (Table 1). One of the reasons for reducing the shoot tip multiplication is the endogenous auxin that causes apical dominance. It was partially released by cytokinin (BA) application to the culture medium. Similarly, nodal (stem) explants performed better in TIS cultures of hybrid chestnut (Vidal et al., 2015) and Malus domestica (Zhu et al., 2005). The acceleration of shoot multiplication can be also achieved by lowering the apical dominance by introducing motion to the culture (Mehrotra et al., 2007). In our study, we have observed the effect of culture immersion on multiplication rate, but only for shoot tip explants (Table 3, Fig. 2). Stem explant cultures in TIS showed the highest multiplication rates, irrespective of immersion frequency. Increasing immersion frequency from 2 to 4 times per day resulted in a five-fold increase in the

Table 1. Mean values of main effects of culture system and explant type on growth and development of Rosa canina

\begin{tabular}{|c|c|c|c|c|c|c|}
\hline Treatment & $\begin{array}{l}\text { Biomass } \\
\text { growth }\end{array}$ & Dry mass content & $\begin{array}{l}\text { Multiplication } \\
\text { rate }\end{array}$ & $\begin{array}{c}\text { Plant height } \\
(\mathrm{mm})\end{array}$ & $\begin{array}{c}\text { Plant height on } \\
\text { solid (mm) }\end{array}$ & $\begin{array}{l}\text { Plant height } \\
\text { increase (\%) }\end{array}$ \\
\hline \multicolumn{7}{|l|}{ Culture system $(\mathrm{C})^{* *}$} \\
\hline S & $2.9 \pm 1.0 \mathrm{a}^{*}$ & $0.20 \pm 0.03 b$ & $0.7 \pm 0.3 c$ & $16.0 \pm 2.2 \mathrm{c}$ & $24.7 \pm 2.8 \mathrm{a}$ & 54 \\
\hline TIS $2 \times 15$ & $4.5 \pm 1.5 \mathrm{~b}$ & $0.17 \pm 0.05 \mathrm{a}$ & $0.5 \pm 0.4 \mathrm{bc}$ & $14.4 \pm 1.6 \mathrm{~b}$ & $40.2 \pm 4.8 b$ & 179 \\
\hline TIS $3 \times 15$ & $5.9 \pm 1.0 \mathrm{bc}$ & $0.24 \pm 0.02 \mathrm{c}$ & $0.6 \pm 0.4 \mathrm{bc}$ & $16.2 \pm 1.4 \mathrm{c}$ & $45.2 \pm 8.2 \mathrm{bc}$ & 179 \\
\hline TIS $4 \times 15$ & $5.3 \pm 1.5 \mathrm{~b}$ & $0.29 \pm 0.03 \mathrm{~d}$ & $0.7 \pm 0.3 c$ & $19.2 \pm 3.4 \mathrm{~d}$ & $39.8 \pm 8.4 b$ & 107 \\
\hline SL & $7.0 \pm 2.2 \mathrm{c}$ & $0.18 \pm 0.05 \mathrm{a}$ & $0.3 \pm 0.2 \mathrm{a}$ & $11.9 \pm 2.2 \mathrm{a}$ & $29.8 \pm 5.5 \mathrm{a}$ & 150 \\
\hline RS & $10.2 \pm 2.2 \mathrm{~d}$ & $0.16 \pm 0.07 \mathrm{a}$ & $0.4 \pm 0.2 \mathrm{ab}$ & $22.5 \pm 5.9 \mathrm{e}$ & $48.7 \pm 8.7 \mathrm{c}$ & 116 \\
\hline \multicolumn{7}{|l|}{ Explant type (E) } \\
\hline Stem explant & $5.3 \pm 2.8 \mathrm{a}$ & $0.18 \pm 0.10 \mathrm{a}$ & $0.7 \pm 0.3 b$ & $15.4 \pm 2.6 \mathrm{a}$ & $39.0 \pm 12.0 \mathrm{a}$ & 153 \\
\hline Shoot tip & $6.6 \pm 2.6 \mathrm{~b}$ & $0.23 \pm 0.10 \mathrm{~b}$ & $0.3 \pm 0.2 \mathrm{a}$ & $18.0 \pm 5.7 \mathrm{~b}$ & $37.1 \pm 9.1 \mathrm{a}$ & 106 \\
\hline Significant effects $(\mathrm{P}<0.01)$ & $\mathrm{C}, \mathrm{E}, \mathrm{C} \times \mathrm{E}$ & $\mathrm{C}, \mathrm{E}, \mathrm{C} \times \mathrm{E}$ & $\mathrm{C}, \mathrm{E}, \mathrm{C} \times \mathrm{E}$ & $\mathrm{C}, \mathrm{E}, \mathrm{C} \times \mathrm{E}$ & $\mathrm{C}, \mathrm{C} \times \mathrm{E}$ & Not analyzed \\
\hline
\end{tabular}

${ }^{* *}$ Culture systems: $\mathrm{S}$ - solid medium (control); TIS 2x15 - temporary immersion system cultures and immersion frequency; SL - stationary liquid cultures; RS cultures in liquid medium on rotary shaker $(100 \mathrm{rpm})$.

${ }^{*}$ Mean values \pm SD $(n=30-60)$ followed by different lower-case letters are significantly different at $P \leq 0.05$ according to Duncan's multiple range test. 
Table 2. Mean values of main effects of culture system and explant type on chlorophylls, carotenoids, total phenolics and soluble sugars contetents in Rosa canina plantlets

\begin{tabular}{|c|c|c|c|c|c|c|}
\hline Treatment & $\begin{array}{l}\text { Chlorophyll } a \\
(\mathrm{mg} / \mathrm{g} \text { FW) }\end{array}$ & $\begin{array}{l}\text { Chlorophyll } b \\
\text { (mg/g FW) }\end{array}$ & $\begin{array}{c}\text { Chlorophylls } \\
a+b \\
(\mathrm{mg} / \mathrm{g} \mathrm{FW}) \\
\end{array}$ & $\begin{array}{c}\text { Carotenoids } \\
\text { (mg/g FW) }\end{array}$ & $\begin{array}{l}\text { Total phenolics } \\
(\mathrm{mg} / \mathrm{g} \mathrm{FW})\end{array}$ & $\begin{array}{c}\text { Soluble sugars } \\
(\mathrm{mg} / \mathrm{g} \text { FW) }\end{array}$ \\
\hline \multicolumn{7}{|l|}{ Culture system $(\mathrm{C})^{* *}$} \\
\hline S & $4.54 \pm 0.75 \mathrm{~d}^{*}$ & $2.38 \pm 0.46 \mathrm{c}$ & $6.92 \pm 1.19 \mathrm{~d}$ & $0.99 \pm 0.24 \mathrm{c}$ & $11.4 \pm 1.7 \mathrm{~b}$ & $8.0 \pm 0.6 b$ \\
\hline TIS $2 \times 15$ & $3.53 \pm 0.63 \mathrm{ab}$ & $1.68 \pm 0.23 \mathrm{a}$ & $5.21 \pm 0.82 \mathrm{ab}$ & $0,57 \pm 0.18 \mathrm{a}$ & $15.8 \pm 8.1 \mathrm{e}$ & $8.7 \pm 1.3 \mathrm{c}$ \\
\hline TIS $3 \times 15$ & $3.88 \pm 0.73 b c$ & $1.87 \pm 0.22 \mathrm{ab}$ & $5.75 \pm 0.94 b c$ & $0.66 \pm 0.16 \mathrm{a}$ & $14.6 \pm 2.3 \mathrm{~d}$ & $7.4 \pm 0.5 \mathrm{a}$ \\
\hline TIS $4 \times 15$ & $3.56 \pm 0.31 \mathrm{ab}$ & $1.71 \pm 0.10 \mathrm{a}$ & $5.27 \pm 0.40 \mathrm{ab}$ & $0.65 \pm 0.03 \mathrm{a}$ & $12.9 \pm 1.1 \mathrm{c}$ & $9.2 \pm 0.5 \mathrm{~d}$ \\
\hline SL & $4.21 \pm 0.92 \mathrm{~cd}$ & $2.04 \pm 0.29 b$ & $6.25 \pm 1.2 c$ & $0.79 \pm 0.26 b$ & $11.3 \pm 2.6 \mathrm{~b}$ & $10.1 \pm 0.7 \mathrm{e}$ \\
\hline RS & $3.29 \pm 0.94 \mathrm{a}$ & $1.79 \pm 0.32 \mathrm{a}$ & $5.07 \pm 1.24 \mathrm{a}$ & $0.56 \pm 0.31 \mathrm{a}$ & $8.8 \pm 2.2 \mathrm{a}$ & $7.1 \pm 0.6 \mathrm{a}$ \\
\hline \multicolumn{7}{|l|}{ Explant type (E) } \\
\hline Stem explant & $3.61 \pm 0.94 \mathrm{a}$ & $1.87 \pm 0.46 \mathrm{a}$ & $5.48 \pm 1.38 \mathrm{a}$ & $0.64 \pm 0.30 \mathrm{a}$ & $11.0 \pm 3.1 \mathrm{a}$ & $8.2 \pm 1,2 \mathrm{a}$ \\
\hline Shoot tip & $4.06 \pm 0.60 \mathrm{~b}$ & $1.95 \pm 0.24 \mathrm{a}$ & $6.01 \pm 0.82 \mathrm{~b}$ & $0.76 \pm 0.18 b$ & $13.9 \pm 4.9 \mathrm{~b}$ & $8.6 \pm 1,4 \mathrm{~b}$ \\
\hline Significant effects $(P<0.01)$ & $\mathrm{C}, \mathrm{E}, \mathrm{C} \times \mathrm{E}$ & $\mathrm{C}, \mathrm{C} \times \mathrm{E}$ & $\mathrm{C}, \mathrm{E}, \mathrm{C} \times \mathrm{E}$ & $\mathrm{C}, \mathrm{E}, \mathrm{C} \times \mathrm{E}$ & $\mathrm{C}, \mathrm{E}, \mathrm{C} \times \mathrm{E}$ & $\mathrm{C}, \mathrm{E}, \mathrm{C} \times \mathrm{E}$ \\
\hline
\end{tabular}

${ }^{* *}$ Culture systems: $\mathrm{S}$ - solid medium (control); TIS $2 \times 15$ - temporary immersion system cultures and immersion frequency; SL - stationary liquid cultures; RS cultures in liquid medium on rotary shaker $(100 \mathrm{rpm})$.

${ }^{*}$ Mean values \pm SD $(\mathrm{n}=30-60)$ followed by different lower-case letters are significantly different at $P \leq 0.05$ according to Duncan's multiple range test.

Table 3. Effects of culture system and explant type on morphological parameters in Rosa canina cultures

\begin{tabular}{|c|c|c|c|c|c|c|c|}
\hline $\begin{array}{l}\text { Culture system } \\
\text { (C) }{ }^{* *}\end{array}$ & $\begin{array}{c}\text { Explant type } \\
\text { (E) }\end{array}$ & Biomass growth & $\begin{array}{c}\text { Dry mass } \\
\text { content }\end{array}$ & $\begin{array}{l}\text { Multiplication } \\
\text { rate }\end{array}$ & $\begin{array}{c}\text { Plant height } \\
(\mathrm{mm})\end{array}$ & $\begin{array}{c}\text { Plant height on } \\
\text { solid (mm) }\end{array}$ & $\begin{array}{l}\text { Plant height } \\
\text { increase (\%) }\end{array}$ \\
\hline$S$ & Stem explant & $2.7 \pm 1.5 \mathrm{a}^{*}$ & $0.23 \pm 0.01 \mathrm{~d}$ & $0.8 \pm 0.4 \mathrm{de}$ & $17.7 \pm 0.7 \mathrm{~d}$ & $24.4 \pm 0.4 \mathrm{a}$ & 38 \\
\hline S & Shoot tip & $3.2 \pm 0.4 \mathrm{ab}$ & $0.18 \pm 0.01 \mathrm{c}$ & $0.5 \pm 0.2 \mathrm{~cd}$ & $14.4 \pm 2.0 \mathrm{bc}$ & $24.9 \pm 4.2 \mathrm{a}$ & 73 \\
\hline TIS $2 \times 15$ & Stem explant & $4.4 \pm 2.3 \mathrm{a}-\mathrm{d}$ & $0.13 \pm 0,03 b$ & $0.9 \pm 0.2 \mathrm{e}$ & $15.3 \pm 1.0 \mathrm{~b}-\mathrm{d}$ & $43.7 \pm 2.8 \mathrm{~d}-\mathrm{f}$ & 186 \\
\hline TIS $2 \times 15$ & Shoot tip & $4.6 \pm 0.1 \mathrm{a}-\mathrm{d}$ & $0.20 \pm 0.02 \mathrm{~cd}$ & $0.1 \pm 0.1 \mathrm{a}$ & $13.5 \pm 1.6 \mathrm{~b}$ & $36.7 \pm 3.4 \mathrm{~cd}$ & 172 \\
\hline TIS $3 \times 15$ & Stem explant & $5.3 \pm 0.2 \mathrm{~b}-\mathrm{d}$ & $0.31 \pm 0.01 \mathrm{f}$ & $1.0 \pm 0.3 \mathrm{e}$ & $15.6 \pm 1.6 \mathrm{~b}-\mathrm{d}$ & $51.1 \pm 4.4 \mathrm{ef}$ & 228 \\
\hline TIS $3 \times 15$ & Shoot tip & $6.4 \pm 0.4 c-e$ & $0.27 \pm 0.01 \mathrm{e}$ & $0.2 \pm 0.1 \mathrm{ab}$ & $16.7 \pm 1.1 \mathrm{~cd}$ & $39.3 \pm 6.6 \mathrm{c}-\mathrm{e}$ & 135 \\
\hline TIS $4 \times 15$ & Stem explant & $4.0 \pm 0.3 \mathrm{a}-\mathrm{c}$ & $0.21 \pm 0.02 \mathrm{~d}$ & $0.9 \pm 0.2 \mathrm{e}$ & $16.5 \pm 0.1 \mathrm{~cd}$ & $33.7 \pm 2.8 \mathrm{bc}$ & 104 \\
\hline TIS $4 \times 15$ & Shoot tip & $6.6 \pm 0.6 \mathrm{de}$ & $0.27 \pm 0.03 \mathrm{e}$ & $0.5 \pm 0.2 \mathrm{~cd}$ & $22.0 \pm 2.5 \mathrm{e}$ & $45.9 \pm 7.7 \mathrm{e}-\mathrm{g}$ & 109 \\
\hline SL & Stem explant & $5.8 \pm 1.7 \mathrm{~cd}$ & $0.12 \pm 0.01 \mathrm{ab}$ & $0.4 \pm 0.2 b c$ & $10.4 \pm 1.3 \mathrm{a}$ & $28.0 \pm 7.8 \mathrm{ab}$ & 170 \\
\hline SL & Shoot tip & $8.3 \pm 2.0 \mathrm{ef}$ & $0.23 \pm 0.02 \mathrm{~d}$ & $0.1 \pm 0.1 \mathrm{a}$ & $13.3 \pm 1.9 \mathrm{~b}$ & $31.6 \pm 1.0 \mathrm{ab}$ & 138 \\
\hline RS & Stem explant & $9.9 \pm 3.0 \mathrm{f}$ & $0.10 \pm 0.02 a$ & $0.5 \pm 0.2 \mathrm{~cd}$ & $17.1 \pm 1.3 \mathrm{~d}$ & $53.1 \pm 6.7 \mathrm{f}$ & 211 \\
\hline RS & Shoot tip & $10.5 \pm 1.7 \mathrm{f}$ & $0.22 \pm 0.03 \mathrm{~d}$ & $0.3 \pm 0.1 \mathrm{a}-\mathrm{c}$ & $27.9 \pm 0.9 \mathrm{f}$ & $44.3 \pm 8.9 \mathrm{~d}-\mathrm{f}$ & 59 \\
\hline
\end{tabular}

${ }^{* *}$ Culture systems: $\mathrm{S}$ - solid medium (control); TIS 2x15 - temporary immersion system cultures and immersion frequency; SL - stationary liquid cultures; RS cultures in liquid medium on rotary shaker $(100 \mathrm{rpm})$.

${ }^{*}$ Mean values \pm SD $(n=30-60)$ followed by different lower-case letters are significantly different at $P \leq 0.05$ according to Duncan's multiple range test.

multiplication intensity of shoot tip cultures. A similar relationship was found in the cultures of Pistacia vera, where the multiplication of nodal explants did not depend on immersion frequency, whereas this relationship was observed for shoot tips (Akdemir et al., 2014). The results may suggest that to increase the efficiency of Rosa canina shoot multiplication, the immersion frequency and/or the cytokinin content in the medium should be increased. In the study of Davoudi Pahnekolay et al. (2016), the addition of $2 \mathrm{mg} \mathrm{dm}^{-3} \mathrm{BA}$ in solid $R$. canina cultures improved the efficiency of axillary shoot multiplication.

Culture system affected plant height during multiplication in different liquid culture systems and subsequent subculture on MS solid medium free of plant growth regulators (Table 1). In both cases the tallest plants were obtained in RS system. SL inhibited shoot elongation either during shoot multiplication (main experiment) or after subculture on solid medium. During multiplication, plant height was dependent on immersion frequency and it increased with higher frequency. Plant height leveled off after 6 weeks of subculture on solid medium (Table 1), however, the greatest increase occurred in the stem explant cultures multiplicated in TIS, with a frequency of 2 and 3 times per day (186\% and $228 \%$, respectively) and in RS (211\%) (Table 3). It was also noted that the constant (SL and RS) or frequent (TIS $4 \times 15 \mathrm{~min}$ ) contact of explants with medium during multiplication created better conditions for shoot tip height growth than for stem explants (Table 3).

Culture systems, where tissues are immersed permanently or temporarily in the culture medium, provide possibility of direct uptake of nutrients and growth regulators through the whole plant surface (Akdemir et al., 2014). This results in a better biomass growth and plant height, but some parameters can also be reduced in the case of worse aeration of the culture. In our study, high biomass increase but low growth, proliferation and dry matter content parameters were obtained in SL cultures. Cultures with increased aeration capacity - RS and TIS - provide better conditions for plant growth and development. Jang $e t$ al. (2016) emphasized that the aeration intensity is one of the most important factors affecting the growth and development of regenerants in liquid media. The gas composition of the air inside the vessel and oxygen content of the medium determines the growth of cells and tissues, and may also be responsible for the occurrence of physiological disorders, including hyperhydricity (Jang et al., 2016; Georgiev et al., 2014). In our study, such physiological disorders were not observed, regardless of the culture system (Figs. 1, 2). 
62
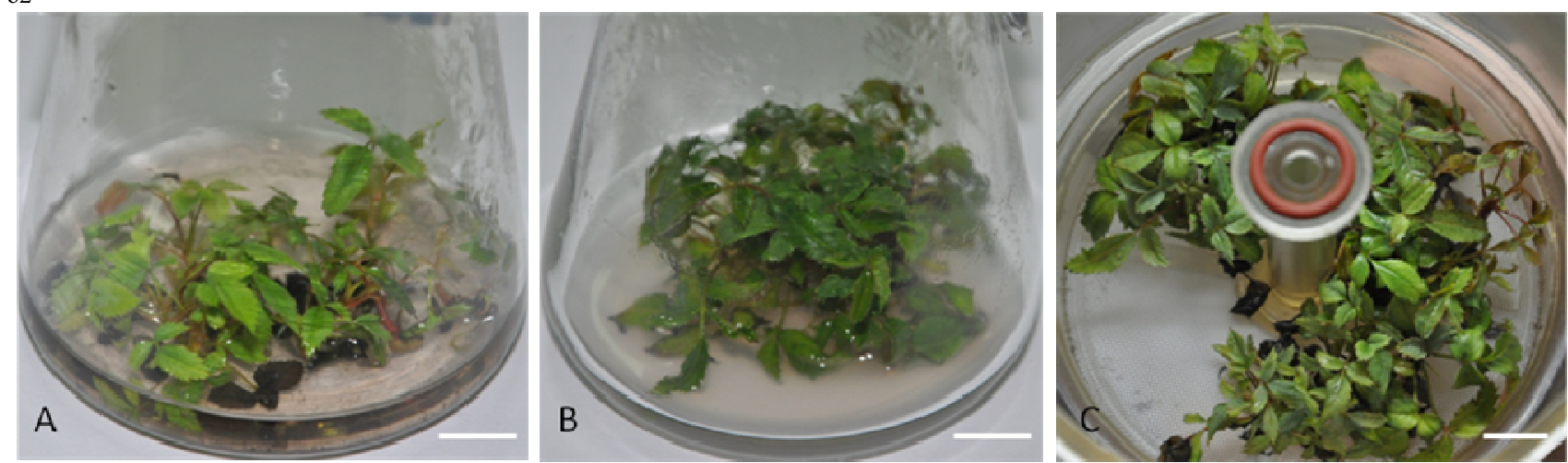

Fig. 1. Stem explant cultures of Rosa canina in different liquid culture systems: stationary liquid system (A), rotary shaker system (B) and temporary immersion system (C). Scale bars $=1 \mathrm{~cm}$
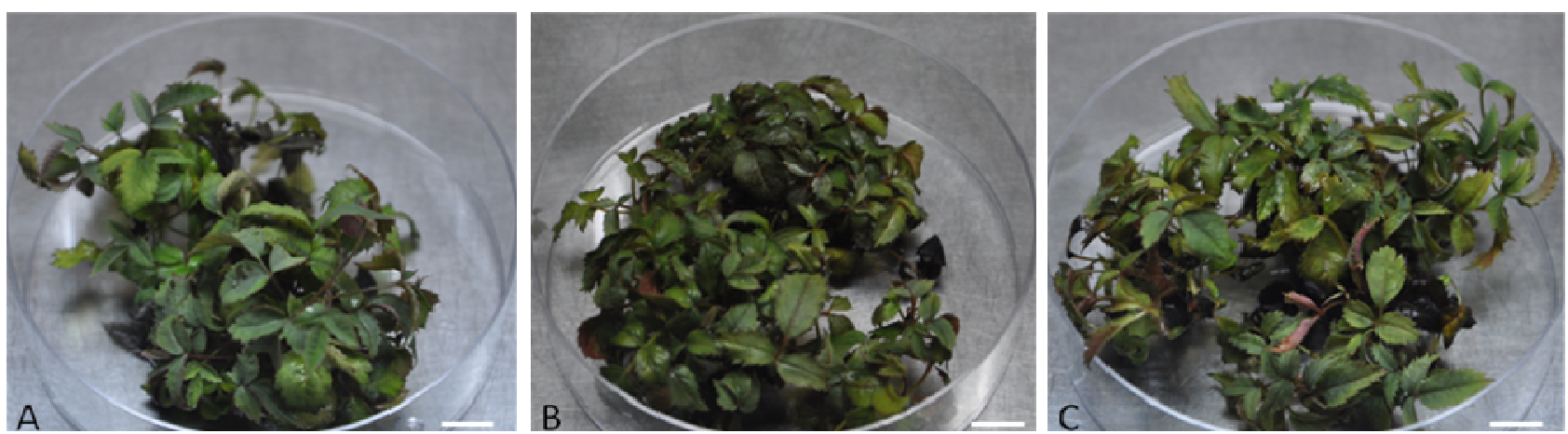

Fig. 2. Shoot tip explant cultures of Rosa canina in temporary immersion (Rita) system: with two immersion periods of 15 min per day (A), three immersion periods of $15 \mathrm{~min}$ per day (B) and four immersion periods of 15 min per day $(\mathrm{C})$. Scale bars $=1 \mathrm{~cm}$

Table 4. Effects of culture system and explant type on biochemical parameters in Rosa canina cultures

\begin{tabular}{|c|c|c|c|c|c|c|c|}
\hline $\begin{array}{l}\text { Culture system } \\
\text { (C) })^{* *}\end{array}$ & Explant type (E) & $\begin{array}{c}\text { Chlorophyll } a \\
(\mathrm{mg} / \mathrm{g} F W)\end{array}$ & $\begin{array}{c}\text { Chlorophyll } b \\
\text { (mg/g FW) }\end{array}$ & $\begin{array}{c}\text { Chlorophylls } \\
a+b \\
(\mathrm{mg} / \mathrm{g} \mathrm{FW})\end{array}$ & $\begin{array}{l}\text { Carotenoids } \\
(\mathrm{mg} / \mathrm{g} \mathrm{FW})\end{array}$ & $\begin{array}{c}\text { Total } \\
\text { phenolics } \\
(\mathrm{mg} / \mathrm{g} \mathrm{FW})\end{array}$ & $\begin{array}{c}\text { Soluble sugars } \\
\text { (mg/g FW) }\end{array}$ \\
\hline$S$ & Stem explant & $5.17 \pm 0.45 \mathrm{e}^{*}$ & $2.69 \pm 0.48 \mathrm{f}$ & $7.86 \pm 0.94 \mathrm{f}$ & $1.20 \pm 0.09 \mathrm{f}$ & $12.8 \pm 0.4 \mathrm{e}$ & $8.4 \pm 0.3 c$ \\
\hline$S$ & Shoot tip & $3.91 \pm 0.17 \mathrm{c}-\mathrm{e}$ & $2.07 \pm 0.04 \mathrm{de}$ & $5.98 \pm 0.22 \mathrm{de}$ & $0.77 \pm 0.03 \mathrm{~d}$ & $9.9 \pm 1.0 \mathrm{bc}$ & $7.6 \pm 0.5 b$ \\
\hline TIS $2 \times 15$ & Stem explant & $2.96 \pm 0.01 \mathrm{ab}$ & $1.51 \pm 0.15 \mathrm{a}$ & $4.47 \pm 0.16 \mathrm{ab}$ & $0.43 \pm 0.02 \mathrm{ab}$ & $8.3 \pm 0.1 \mathrm{ab}$ & $7.5 \pm 0.3 \mathrm{ab}$ \\
\hline TIS $2 \times 15$ & Shoot tip & $4.09 \pm 0.16 \mathrm{de}$ & $1.86 \pm 0.14 \mathrm{a}-\mathrm{d}$ & $5.95 \pm 0.16 \mathrm{de}$ & $0.71 \pm 0.14 \mathrm{~cd}$ & $23.4 \pm 2.5 \mathrm{~g}$ & $9.8 \pm 0.7 \mathrm{~d}-\mathrm{f}$ \\
\hline TIS $3 \times 15$ & Stem explant & $4.30 \pm 0.15 \mathrm{e}$ & $2.05 \pm 0.04 \mathrm{c}-\mathrm{e}$ & $6.35 \pm 0.18 \mathrm{e}$ & $0.74 \pm 0.02 \mathrm{~cd}$ & $15.1 \pm 0.7 \mathrm{f}$ & $7.4 \pm 0.6 \mathrm{ab}$ \\
\hline TIS $3 \times 15$ & Shoot tip & $3.47 \pm 0.90 \mathrm{~cd}$ & $1.69 \pm 0.16 \mathrm{a}-\mathrm{c}$ & $5.16 \pm 1.06 \mathrm{~b}-\mathrm{d}$ & $0.58 \pm 0.21 b c$ & $14.0 \pm 3.2 \mathrm{ef}$ & $7.4 \pm 0.3 \mathrm{ab}$ \\
\hline TIS $4 \times 15$ & Stem explant & $3.36 \pm 0.32 \mathrm{bc}$ & $1.64 \pm 0.12 \mathrm{ab}$ & $5.00 \pm 0.41 b c$ & $0.64 \pm 0.05 \mathrm{~cd}$ & $13.8 \pm 0.7$ ef & $9.1 \pm 0.5 \mathrm{~d}$ \\
\hline TIS $4 \times 15$ & Shoot tip & $3.77 \pm 0.12 \mathrm{c}-\mathrm{e}$ & $1.77 \pm 0.06 \mathrm{a}-\mathrm{d}$ & $5.54 \pm 0.10 \mathrm{c}-\mathrm{e}$ & $0.65 \pm 0.01 \mathrm{~cd}$ & $12.0 \pm 0.2 \mathrm{de}$ & $9.2 \pm 0.6 \mathrm{de}$ \\
\hline SL & Stem explant & $3.38 \pm 0.19 b c$ & $1.77 \pm 0.06 \mathrm{a}-\mathrm{d}$ & $5.15 \pm 0.25 b-d$ & $0.56 \pm 0.05 b c$ & $8.8 \pm 0.2 \mathrm{a}-\mathrm{c}$ & $9.9 \pm 0.7 \mathrm{ef}$ \\
\hline SL & Shoot tip & $5.04 \pm 0.08 \mathrm{e}$ & $2.30 \pm 0.01 \mathrm{e}$ & $7.35 \pm 0.09 \mathrm{f}$ & $1.03 \pm 0.01 \mathrm{e}$ & $13.7 \pm 0.8 \mathrm{ef}$ & $10.4 \pm 0.6 \mathrm{f}$ \\
\hline RS & Stem explant & $2.48 \pm 0.38 \mathrm{a}$ & $1.57 \pm 0,21 \mathrm{a}$ & $4.05 \pm 0.59 \mathrm{a}$ & $0.31 \pm 0.08 \mathrm{a}$ & $7.1 \pm 0.4 \mathrm{a}$ & $6.8 \pm 0.5 \mathrm{a}$ \\
\hline RS & Shoot tip & $4.09 \pm 0.31 \mathrm{de}$ & $2.00 \pm 0.27 \mathrm{~b}-\mathrm{e}$ & $6.10 \pm 0.59 \mathrm{de}$ & $0.82 \pm 0.19 \mathrm{~d}$ & $10.5 \pm 1.8 \mathrm{~cd}$ & $7.3 \pm 0.5 \mathrm{ab}$ \\
\hline
\end{tabular}

${ }^{* *}$ Culture systems: S - solid medium (control); TIS 2x15 - temporary immersion system cultures and immersion frequency; SL - stationary liquid cultures; RS cultures in liquid medium on rotary shaker $(100 \mathrm{rpm})$.

${ }^{*}$ Mean values \pm SD $(n=30-60)$ followed by different lower-case letters are significantly different at $P \leq 0.05$ according to Duncan's multiple range test.

The analysis of variance showed significant differences in the interaction between explants type and the culture system for all investigated biochemical parameters (Table 2).

The highest content of chlorophyll $a, b, a+b$ and carotenoids give expression on the high multiplication rate of plantlets cultured on solid medium. The lowest level of all biochemical analyzed parameters was observed in the RS culture system and corresponded with the lowest dry mass content and multiplication rate. Chlorophylls and carotenoids play multifarious roles in the protection against oxidative damage (Jaleel et al., 2009); moreover, their content closely depends on the environment of growth and development of plants (Chen and Chen, 2008).
In addition, a lower concentration of chlorophyll $b$ with respect to chlorophyll $a$ was noted in all culture systems, regardless of the type of explant used. It can be assumed that the in vitro culture functions as a stress factor for plants, resulting in a decrease in the concentration of chlorophyll $b$. Similar results was reported by Jaleel et al. (2009), where stress reduced the content of chlorophylls and decrease of chlorophyll $b$ was greater than of chlorophyll $a$. Our study in TIS showed a relatively low level of photosynthetic pigment content. Lower physiological parameters were also observed in periodically immersed chrysanthemum cultures (Hahn and Paek, 2005). In turn, TIS increased the levels of 
chlorophyll and carotenoids in cherry and peach cultures (Damiano et al., 2005).

The high content of phenolic compounds was observed in TIS compared to other culture systems. Increased frequency of immersion reduced the concentration of these compounds from 15.8 to $12.9 \mathrm{mg} / \mathrm{g} \mathrm{FW}$ (Table 2). Phenolics function as natural antioxidants and can protect plants against in vitro culture stress, including explant excision, medium composition and vessel atmosphere (van Staden, 2006). In our experiment, their excessive production $(23.40 \mathrm{mg} / \mathrm{g} \mathrm{FW})$ in shoot tips cultured in TIS $2 \times 15$ was the result of unfavorable culture conditions, i.e., low frequency of immersion (Tables 2, 4). Phenolics are an important group of secondary metabolites and are effective in plant growth regulation, cell differentiation and organogenesis (Ozyigit et al., 2007). High productivity of phenolic compounds can be used for commercial production of $R$. canina biomass containing antioxidant compounds. The highest concentration of carbohydrates $(10.1 \mathrm{mg} / \mathrm{g} \mathrm{FW})$ was found in plantlets that were cultured in SL, while the lowest concentration $(7.1 \mathrm{mg} / \mathrm{g} \mathrm{FW})$ was observed in plantlets in RS. The accumulation of high level of free fructose was observed in SL of cherry and peach cultures (Damiano et al., 2005). Studies of Van den Ende and Valluru (2009) demonstrated that sucrose at low concentrations might serve as a substrate for stress-induced modifications, whereas at higher concentrations it may function directly as a protective agent.

\section{Conclusions}

Systems based on liquid media and bioreactors can significantly increase the multiplication rate and secondary metabolites' production in Rosa canina. The multiplication efficiency in liquid cultures depends on the degree of culture aeration, which is associated with the type of the system. Best morphological parameters during plantlets production and satisfactory quality of regenerants are achieved in the TIS cultures immersed at least three times (for 15 minutes) per 24 hours.

\section{Acknowledgements}

This work was supported by the Polish Ministry of Higher Education (DS 3500).

\section{References}

Akdemir H, Süzerer V, Onay A, Tilkat E, Ersali Y, Çiftçi YO (2014). Micropropagation of the pistachio and its rootstocks by temporary immersion system. Plant Cell Tissue and Organ Culture 117:65-76.

Arencibia AD, Vergara C, QuirozK, Carrasco B, Garcia-Gonzales R(2013). Establishment of photomixotrophic cultures for raspberry micropropagation in Temporary Immersion Bioreactors (TIBs). ScientiaHorticulturae 160:49-53.

Bayanati M, Davoodi D, Kermani MJ (2015). Effect of agar and different culture media on the micropropagation of Rosa hybrida cr. "Black Baccara'.Journal of Ornamental Plants 5:75-81.

Berthouly M, Etienne H (2005). Temporary immersion system: a new concept for use liquid medium in mass propagation. In: Hvoslef-Eide AK, Preil W (Eds). Liquid culture systems for in vitro plant propagation. Dordrecht, The Netherlands: Springerpp 165-195.
Cavallaro V, Patane C, Cosentino SL, Di Silvestro I, Copani V (2014). Optimizing in vitro large scale production of giant reed (Arundo donax L.) by liquid medium culture. Biomass and Bioenergy 69:21-27.

Cheikh-Affene ZB, Haouala F, Trabelsi N, Boulaaba M, Ksouri R, Harzallah-Skhiri F (2013). Pomological description and chemical composition of rose hips gathered on four Rosa species section Caninae growing wild in Tunisia. International Journal of Agricultural Science and Technology 1(3):43-50.

Chen JCh, Chen ChT (2008). Correlation analysis between indices of tree leaf spectral reflectance and chlorophyll content. The International Archives of the Photogrammetry, Remote Sensing and Spatial Information Sciences. Vol.XXXVII. PartB7. Beijing

Chu CY, Knight SL, Smith MAL (1993). Effect of liquid culture on the growth and development of miniature rose (Rosa chinensis Jacq. 'Minima'). Plant Cell Tissue and Organ Culture 32:329-334.

Damiano C, La Starza SR, Monticelli S, Gentile A, Caboni E, Frattarelli A (2005). Propagation of Prunus and Malus by temporary immersion. In: Hvoslef-Eide AK, Preil W (Eds).Liquid culture systems for in vitro plant propagation. Dordrecht, The Netherlands: Springer pp 243-251.

Davoudi Pahnekolay M, Tehranifar A, Samiei L, Shoor M (2016). Optimization of the micropropagation protocol of two native rose species of Iran (Rosa canina and Rosa eggeriana). Acta Horticulturae 1131:87-96.

Debnath SC (2009). Characteristics of strawberry plants propagated by in vitro bioreactor culture and ex vitro propagation method. Engineering in Life Sciences 9:239-246.

Debnath SC (2014). Bioreactor-induced adventitious shoot regeneration affects genotype-dependent morphology but maintains clonal fidelity in red raspberry. In Vitro Cellular \& Developmental Biology - Plant 50:777-788.

Debnath SC (2016). Temporary immersion and stationary bioreactors for mass propagation of true-to-type highbush, half-high, and hybrid blueberries (Vaccinium spp.). The Journal of Horticultural Science and Biotechnology 92(1):72-80.

Demir F, Özkan M (2001). Chemical and technological properties of rose (Rosa canina L.) fruits grown wild in Turkey. Journal of Food Engineering 47:333-336.

Dubois M, Gilles KA, Hamilton JK, Roberts PA, Smith F (1956). Colorimetric method for determination of sugars and related substances. Analytical Chemistry 28:350-356.

Ercisli S (2005). Rose (Rosa spp.) germplasm resources of Turkey. Genetic Resources and CropEvolution 52:787-795.

Escalona M, Samson G, Borroto C, Desjardins Y (2003). Physiology of effects of temporary immersion bioreactors on micropropagated pineapple plantlets. In Vitro Cellular \& Developmental Biology - Plant 39:651-656.

Georgiev V, Schumann A, Pavlov A, Bley T (2014). Temporary immersion systems in plant biotechnology. Engineering in Life Sciences 14:607621.

Ghashghaie J, Brenckmann F, Saugier B (1991). Effects of agar concentration on water status and growth of rose plants cultured in vitro. Physiologia Plantarum 82:73-78. 
64

Ginova A, Tsvetkov I, Kondakova V (2012). Rosa damascene Mill.: An overview for evaluation of propagation methods. Bulgarian Journal of Agricultural Science 18:545-556.

Gunes M (2010). Pomological and phenological characteristics of promising rose hip (Rosa) genotypes. African Journal of Biotechnology 9(38):6301-6306.

Hahn EJ, Paek KY (2005). Multiplication of Chrysanthemum shoots in bioreactors as affected by culture method and inoculation density of single node stem. Plant Cell Tissue and Organ Culture 81(3):301-306.

Jang HR, Lee HJ, Shohael AM, Park BJ, Paek KY, Park SY (2016). Production of biomass and bioactive compounds from shoot cultures of Rosa rugosa using a bioreactor culture system. Horticulture Environment and Biotechnology 57:79-87.

Jaleel CA, Riadh K, Gopi R, Manivannan P, Inès J, Al-Juburi HJ, ChangXing Z, Hong-Bo S, Panneerselvam R (2009). Antioxidant defense responses: physiological plasticity in higher plants under abiotic constraints. Acta Physiologiae Plantarum 31:427-436.

Kwaśniewska E, Dziedzic E, Pawłowska B (2017). Integration of cryopreservation and tissue culture for germplasm conservation and propagation of Rosa pomifera 'Karpatia'. Notulae Botanicae Horti AgrobotaniciCluj-Napoca45(1):208-214.

Lichtenthaler HK, Wellburn AR (1983). Determinations of total carotenoids and chlorophylls a and b of leaf extracts in different solvents. Biochemical Society Transactions 11:591-592.

Lorenzo JC, González BL, Escalona M, Teisson C, Borroto C (1998). Sugarcane shoot formation in an improved temporary immersion system. Plant Cell Tissue and Organ Culture 54:197-200.

Malik M (2008). Comparison of different liquid/solid culture systems in the production of somatic embryos from Narcissus L. ovary explants. Plant Cell Tissue and Organ Culture 94:337-345.

Malik S, Sharma M, Ahuja PS (2016). An efficient and economic method for in vitro propagation of Amebia euchroma using liquid culture system. American Journal of Biotechnology and Medical Research 1:19-25.

MehrotraS, Goel MK, Kukreja AK, Mishra BN (2007). Efficiency of liquid culture systems over conventional micropropagation: A progress towards commercialization. African Journal of Biotechnology 6:1484 1492.

Mosqueda Frómeta O, Escalona Morgado MM, Teixeira da Silva JA, Pina Morgado MM, Daquinta Gradaille MA (2017). In vitro propagation of Gerbera jamesonii Bolus ex Hooker $\mathrm{f}$. in a temporary immersion bioreactor.Plant Cell Tissue and Organ Culture 129(3):543-551.

Murashige T, Skoog F (1962). A revised medium for rapid growth and bioassays with tobacco tissue cultures. Physiologia Plantarum 15:473497.

Ozyigit II, Kahraman MV, Ercan O (2007). Relation between explant age, total phenols and regeneration response in tissue cultured cotton (Gossypium hirsutum L.). African Journal of Biotechnology 6(1):3-8.

Pati PK, Rath SP, Sharma M, Sood A, Ahuja PS (2006). In vitro propagation of rose-a review. Biotechnology Advances 24:94-114.
Pati PK, Sharma M, Sood A, Ahuja, PS (2005). Micropropagation of Rosa damascena and $R$ bourboniana in liquid cultures. In: Hvoslef-Eide AK, Preil W (Eds). Liquid culture systems for in vitro plant propagation. Dordrecht, The Netherlands: Springer pp 373-385.

Pawłowska $\mathrm{B}$ (2011). The effect of $\mathrm{BA}$ and $\mathrm{GA}_{3}$ on shoot multiplication in in vitro cultures of Polish wild roses. Folia Horticulturae 23:145-149.

Pawłowska B, Szewczyk-Taranek B (2014). Droplet vitrification cryopreservation of Rosa canina and Rosa rubiginosa using shoot tips from in situ plants. Scientia Horticulturae 168:151-156.

Popek R(2002). Róże dziko rosnace Polski. Plantpress, Kraków (in Polish).

Ramírez-Mosqueda MA, Iglesias-Andreu LG (2016). Evaluation of different temporary immersion systems (BIT, BIG, and $\mathrm{RITA}^{\circ}$ ) in the micropropagation of Vanilla planifolia Jacks. In Vitro Cellular \& Developmental Biology - Plant 52:154-160.

Singleton VS, Rossi JJA (1965). Colorimetry of total phenolics with phosphomolybdic phosphotungstic acid reagent. American Journal of Enology and Viticulture 16:144158.

Stănilă A, Diaconeasa Z, Roman I, Sima N, Măniutiu D, Roman A, Sima R (2015). Extraction and characterization of phenolic compounds from rose hip (Rosa canina L.) using liquid chromatography coupled with electrospray ionization - mass spectrometry. Notulae Botanicae Horti AgrobotaniciCluj-Napoca43(2):349-354

Van den Ende W, Valluru R (2009). Sucrose, sucrosyl oligosaccharides, and oxidative stress: scavenging and salvaging? Journal of Experimental Botany 60:9-18.

van Staden J, Fennell CW, Taylor NJ (2006). Plant stress in vitro: the role of phytohormones. Acta Horticulturae 725:55-62

Vidal N, Blanco B, Cuenca B (2015). A temporary immersion system for micropropagation of axillary shoots of hybrid chestnut. Plant Cell Tissue and Organ Culture 123:229-243.

Vukosavljev M,ZhangJ, Esselink GD, van't Westende WPC, Cox P, Visser RGF, Arens P, Smulders MJM (2013). Genetic diversity and differentiation in roses: a garden rose perspective. Scientia Horticulturae 162:320-332.

Welander M, Persson J, Asp H, Zhu LH (2014). Evaluation of a new vessel system based on temporary immersion system. Scientia Horticulturae 179:227-232

Wissemann V, Ritz CM (2007). Evolutionary patterns and processes in the genus Rosa (Rosaceae) and their implications for host-parasite coevolution. Plant Systematics and Evolution 266(1-2):79-89.

Zhu L-H, Li X-Y, Welander M (2005). Optimization of growing conditions for the apple rootstock M26 grown RITA containers using temporary immersion principle. Plant Cell Tissue and Organ Culture 81:313-318.

Zielińnki J (1985). Studia nad rodzajem Rosa L. Systematyka sekcji Caninae DC. em. Christ [Study on the genus Rosa L. systematics, section Caninae DC. em. Christ.]. Arboretum Kórnickie 30:3-109. 